\title{
Nutritional ecology of the ascidian Pyura stolonifera: influence of body size, food quantity and quality on filter-feeding, respiration, assimilation efficiency and energy balance
}

\author{
D. W. Klumpp* \\ Zoology Department, University of Cape Town, South Africa
}

\begin{abstract}
Effects of body size, cell density and food type on filtration rate, respiration rate and assimilation efficiency in the ascidian Pyura stolonifera were determined using a continuous-flow circulating seawater system. Filtration and respiration rates were related to body size according to the regressions: FR $\left(\mathrm{ml} \mathrm{min}^{-1}\right)=8.15 \mathrm{~W}^{0.70}$ and $\mathrm{RR}\left(\mathrm{ml} \mathrm{h}^{-1}\right)=0.14 \mathrm{~W}^{0.95}$. Assimilation efficiency was independent of body size for the consumption of the alga Dunaliella primolecta but was correlated $(A E=21.1+3.3 \mathrm{~W}, \mathrm{r}=0.66)$ with size for natural food. Different types of food, such as phytoplankton species and kelp detritus which occur in the natural environment, were filtered by the ascidian at equal efficiency and rate. Under controlled conditions, the organic fraction of kelp particles is assimilated at $42 \%$ efficiency while $D$. primolecta cells are assimilated at $75 \%$ efficiency. Food in nature, comprising a high proportion of detritus with varying amounts of silt, was assimilated at $34 \%$ efficiency. Filtration, respiration and assimilation rate were all independent of cell density which varied between 1.0 and $70 \times 10^{6}$ cells $1^{-1}$ of $D$. primolecta. At the lower cell densities there was a 'switching-off' of filtering. High silt loads ( $25 \mathrm{mg} \mathrm{l}^{-1}, 3 \% \mathrm{OM}$ ) or high density of large-sized particles (> $65 \mu \mathrm{m}$ ) resulted in 'backsquirting' to reject this material through the inhalent siphon. Additions of silt which produce particle concentrations found in the natural environment of $P$. stolonifera did not affect filtration rate. Net energy balance and the conversion efficiency for artificial and natural diets were estimated. The potential for utilization of natural food resources by $P$. stolonifera is compared with other members of the filter-feeding community.
\end{abstract}

\section{INTRODUCTION}

Filter feeders often account for the greater part of the biomass and production of consumers in the intertidal and sublittoral communities of rocky shores along the coast of South Africa (Velimirov et al., 1977; Field et al., 1980a; McQuaid, 1980). These rocky shore communities are principally formed by several species of mussels (Aulacomya ater, Chromytilus meridionalis and Perna perna), of sponges, holothurians and barnacles and the ascidian Pyra stolonifera. The upwelling region along the west coast, with its associated kelpbeds, is of considerable economic importance and

\footnotetext{
- Present address: Biologische Anstalt Helgoland, Notkestraße 31, D-2000 Hamburg 52, Federal Republic of Germany
}

therefore has been studied in detail by researchers of the multidisciplinary Benguela Ecology Programme at the University of Cape Town. This research has determined the origin, scale and fate of primary production (for review, see Newell et al., 1982) and the energetics of consumers including the mussels $A$. ater (Griffiths \& King, 1979; Stuart, 1982) and C. meridionalis (Griffiths, $1980 \mathrm{a}, \mathrm{b})$. However, there is little information on the ecophysiology of ascidians and of other filter feeders which comprise some $40 \%$ of the total animal biomass in the kelp beds.

Several studies on ascidians from European waters have dealt with rates of water transport (Hecht, 1916; Hoyle, 1953; Carlisle, 1966; Holmes, 1973; Fiala-Médioni, 1978a, b, c, 1979a), filtration (Jørgensen and Goldberg, 1953; Holmes, 1973; Fiala-Médioni, 1973, 1974, 1978b; Randløv and Riisgård, 1979), respiration 
(Jørgensen, 1952; Fisher, 1976; Fiala-Médioni, 1979b) as well as with efficiency of assimilation (Fiala-Médioni, 1973, 1974, 1978c, 1979a) and particle retention (Jørgensen, 1949, 1952; Fiala-Médioni, 1978b; Randløv and Riisgård, 1979). These studies indicate that ascidians are able to process large volumes of water $\left(50 \mathrm{ml} \mathrm{min}{ }^{-1}\right.$ for a standard individual of $1 \mathrm{~g}$ total dry weight). Filtration rate increases as a function of weight according to the normal power exponent of $2 / 3$ and food is utilised at relatively high efficiency $(80$ to $90 \%$ ). The suspended particulate material potentially available to natural populations of filter feeders inhabiting coastal regions is composed of varying proportions of silt, phytoplankton cells, detritus and bacteria. However, limited efforts have been made to measure filtration and digestion in ascidians provided with food that resembles the composition of natural seston. Notable exceptions were Fiala-Médioni (1978a) who determined pumping rate of ascidians in the field and Robbins (1983) who examined filtration and ingestion in two species of ascidians exposed to varying silt loads, apparently in the absence of organic matter. Other environmental factors which affect nutritional processes in ascidians include ration level (Fiala-Médioni, 1979a), temperature (Holmes, 1973; Fiala-Médioni, 1978c; Robbins, 1983) and oxygen tension (Fiala-Médioni, 1979b).

Pyura stolonifera (Heller) is a large solitary ascidian with a wide distribution along the coast of southern Africa from South West Africa to Moçambique (Day, 1974). It occurs from $5 \mathrm{~m}$ depth to the sublittoral and may form dense bands along coasts where there is maximum exposure to waves and currents. The closely related species from Australasia ( $P$. praeputialis) and Chile ( $P$. chilensis) occupy the same niche at great density over vast stretches of coastline (Dakin et al., 1948; Millar, 1971). Past studies on P. stolonifera have been concerned with ecology (Morgans, 1959; Day, 1969, 1974), morphology, functional anatomy (Day, 1974), larval development (Griffiths, 1975), biomass and production (Van Driel, 1978; Field et al., 1980a; Berry, 1982). Stuart and Klumpp (1984) examined particle size selection in $P$. stolonifera and other dominant filter feeders of the kelp beds. They conclude that $P$. stolonifera retains with $100 \%$ efficiency particles in the size range 0.5 to $20 \mu \mathrm{m}$, and these represent $80 \%$ of the volume of natural suspended matter. There are no other reliable data on aspects of energetics in this ascidian, such as water transport, respiration rate, and assimilation efficiency.

This paper reports on the nutritional ecology of Pyura stolonifera. Feeding, respiration and assimilation rates in ascidians of a wide range of body size have been examined under various conditions of food quantity and quality. Results are discussed in relation to the well documented conditions of the natural environment of the southern Cape coast in order to estimate energy balance of ascidians in nature.

\section{MATERIALS AND METHODS}

Field sampling. Ascidians were collected from (1) the outer wall of Kalk Bay harbour, (2) the rocky shore at Blaubergstrand and (3) the sandflats of Langebaan Lagoon in the S.W. Cape of South Africa (Fig. 1). Using SCUBA and a wedged lever, specimens were

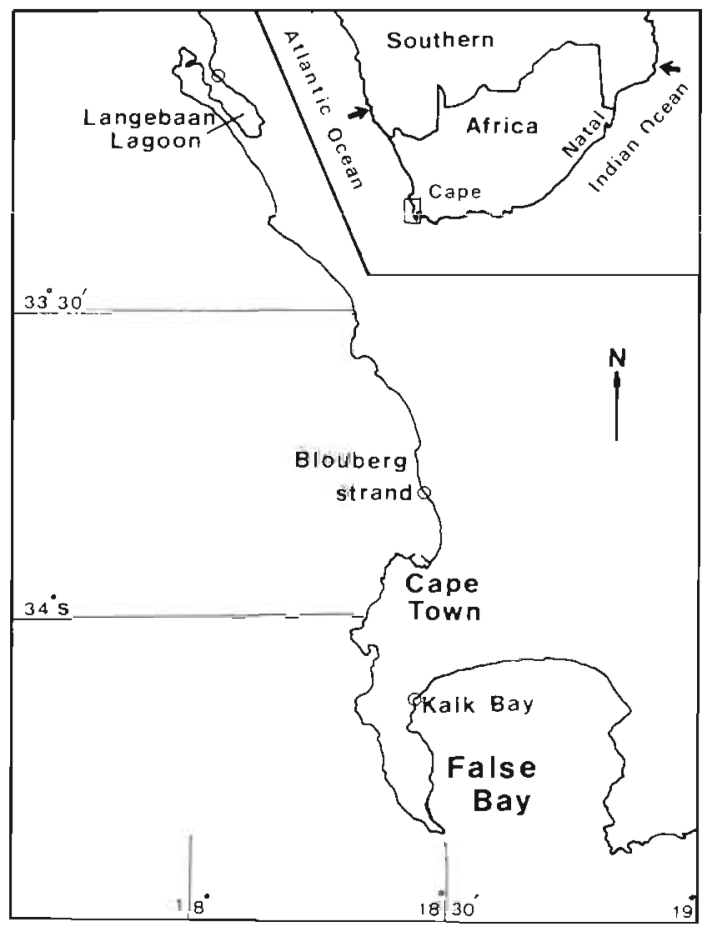

Fig. 1. Map of sampling stations and other locations mentioned in text. Arrows: distribution of Pyura stolonifera on the coast of southern Africa

detached from rock substrates without damage to the test. The form inhabiting sandflats has a root-like extention to the test and these were excavated intact. Samples were taken from the upper $1 \mathrm{~m}$ of the colony at Kalk Bay and from a similar tidal height (LWS) at Blauberg. Samples of ascidians for the estimation of filtration and respiration rates as a function of body size were collected from the 3 locations between May and July 1982. Effects of environmental variables such as silt and seston content of the water column and quantity and quality of suspended food particles on these functions were examined in Kalk Bay individuals in August and September. Assimilation efficiency in relation to the variables mentioned above was studied 
during November and December. The following authors have described the physical, chemical and biological characteristics of False Bay: Griffiths (1980b), McQuaid (1980), Cliff (1982a, b); Southwest Cape: Field et al. (1980a, b) and Langebaan Lagoon: Christie and Moldan (1977), Du Plessis (1977), Henry et al. (1977) and Mazure and Branch (1979).

Experimental procedures. Following collection, ascidians were placed in aquaria as soon as possible. The tests were cleaned of debris and attached organisms and then carefully washed under flowing seawater.

Filtration and respiration. Fig. 2 shows the flow system used for measurement of filtration and respiration. temperature approximates the annual mean for inshore waters of False Bay (Cliff, 1982b). Food concentration was maintained at a desired level by an automatic feeding device incorporating a gravity-feed dosing valve (V) controlled via an adjustable threshold relay switch (RS) and a photoelectric cell (PEC) density detector. The 'feeder' maintained cell concentration within narrow limits, e.g. at the standard experimental concentration of $20.10^{6}$ cells Dunaliella primolecta $1^{-1}$, the variation over $24 \mathrm{~h}$ was $\pm 4 \%$ and increased at the lower cell concentrations used $\left(12 \%\right.$ at $1.3 .10^{6}$ cells $\left.1^{-1}\right)$. Water in the system was changed every second day.

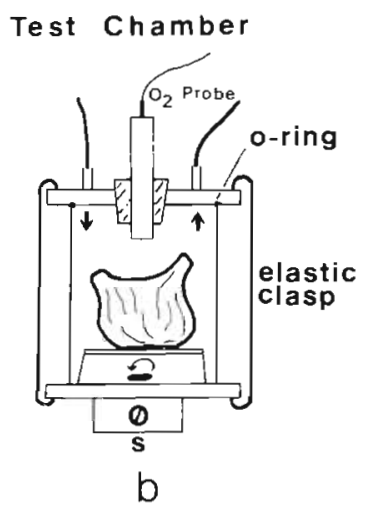

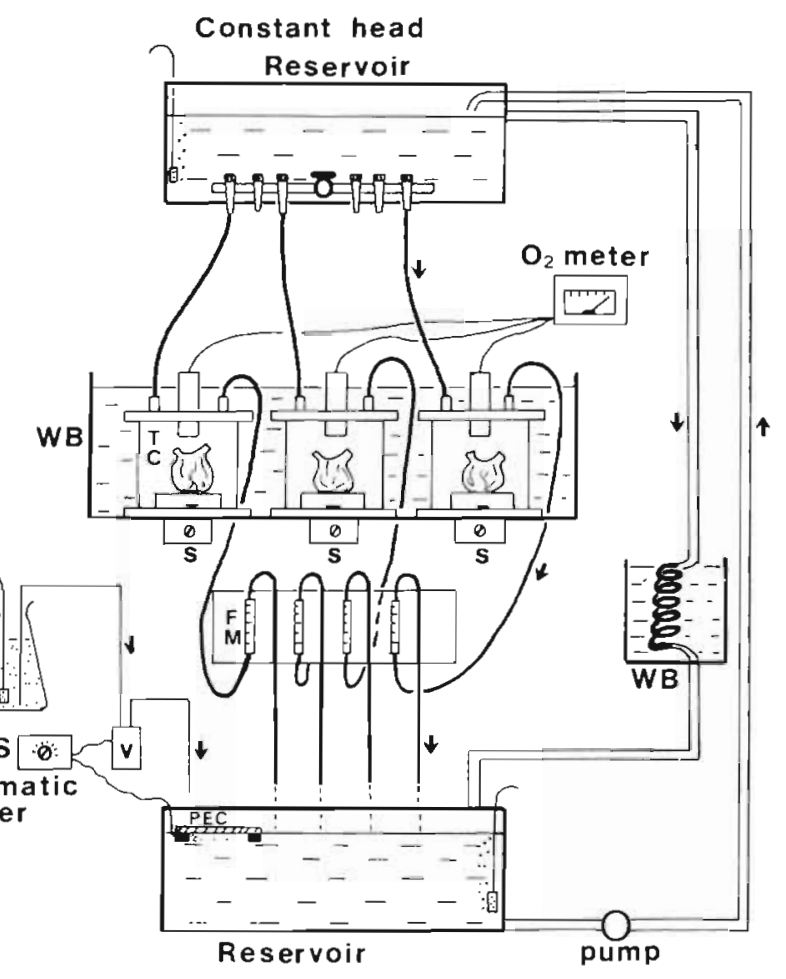

Fig. 2. (a) Closed-circulation system devised for measurement of filtration and respiration rates. See text for explanation; (b) test chamber in detail

a

The principle of such systems and their advantages over static systems were reviewed in Bayne et al. (1976). The system contained a total of $100 \mathrm{l}$ of filtered (Sartorius, $1.0 \mu \mathrm{m} ; 142 \mathrm{~mm}$ diam) Kalk Bay seawater distributed by constant pumping ( $41 \mathrm{~min}^{-1}$ ) between an upper and lower reservoir, each of which was further circulated by aeration and submersible pumps. Water flowed under gravity and the control of flow meters (range: 5-200 $\mathrm{ml} \mathrm{min}^{-1}$ ) from the header tank through perspex test chambers (TC), each containing one ascidian. Water in each test chamber was mixed by

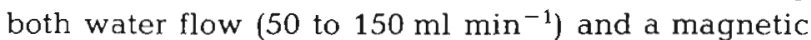
stirrer (S). A water bath (WB) maintained the temperature of the chamber water at $14{ }^{\circ} \mathrm{C}\left( \pm 0.5 \mathrm{C}^{\circ}\right)$. This
Filtration rate (FR) in $\mathrm{ml} \mathrm{min}^{-1}$, defined as the volume of water cleared of particles in unit time, was calculated from the cell concentration of water entering $\left(\mathrm{C}_{\mathrm{i}}\right)$ and leaving $\left(\mathrm{C}_{\mathrm{o}}\right)$ the test chamber and the flow rate $(F)$ in $\mathrm{ml} \mathrm{min}^{-1}$ according to the following formula:

$$
\mathrm{FR}=\frac{\mathrm{C}_{\mathrm{i}}-\mathrm{C}_{\mathrm{o}}}{\mathrm{C}_{\mathrm{o}}} \times \mathrm{F}
$$

By adjustment of flow rate the concentration of the outlet was maintained at between 80 and $90 \%$ of $C_{i}$. Furthermore, $C_{0}$ closely approximated the cell concentration inside the chambers which is the ideal denominator in the above formula (Hildreth and Crisp, 
1976). Since Pyura stolonifera is found to retain these cells with $100 \%$ efficiency (Stuart and Klumpp, 1984) these measurements of filtration rate are equivalent to pumping rate. Particle concentration was measured using a model TA II Coulter counter fitted with a 70 or $280 \mu \mathrm{m}$ aperture tube. Only channels containing the actual particle size range were counted and from this blanks were subtracted to reduce the effect of nonparticle interference. Preliminary trials in which animals were monitored over several days showed that filtration rate in $P$. stolonifera required a period of 3 to $8 \mathrm{~h}$ to stabilise after placement in the test chambers (Fig. 3). Furthermore, once the filtration rate had stabilised it continued to fluctuate considerably about a mean level (Fig. 3) and continued with this pattern for at least $5 \mathrm{~d}$. Such variability in filtration rate is a characteristic of bivalves (Winter, 1969; Griffiths, 1980a) and ascidians (Holmes, 1973; Fiala-Médioni, 1974). For these reasons all filtration rate measurements on $P$. stolonifera were made after the test animals had been in the chambers and feeding for a period of not less than $12 \mathrm{~h}$ (usually overnight). At least 5 consecutive rate measurements were then made for each test animal at intervals of approximately $1 \mathrm{~h}$, from which the mean was calculated.

Rates of oxygen consumption were measured following filtration rate determinations, by first sealing the test chambers at the inlet and outlet tubes (Fig. 2b). Water was maintained in circulation by the magnetic stirrer bar, while decline in oxygen tension was monitored over a period of up to $60 \mathrm{~min}$ by inserted YSI $\mathrm{P} \mathrm{O}_{2}$ probes coupled via a switch-gear mechanism to a multichannel chart recorder. The decline in oxygen tension was not allowed to exceed $10 \%$ of the original and in all cases followed a smooth linear pattern. The probes were calibrated at regular intervals using Winkler titrations (Strickland and Parsons, 1968). Filtration and respiration rates were related to the dry $\left(70^{\circ} \mathrm{C}\right.$ oven for $\left.5 \mathrm{~d}\right)$ mass of animal, minus test. This tissue had a wet: dry weight ratio of 8:0.

Food used in experiments on the effects of body size, ration level and silt load on filtration and respiration rates was Dunaliella primolecta (sterile culture) in its exponential growth phase. To determine the body-size relation, up to 18 ascidians were collected on several occasions, 6 of which could be tested at any one time. Remaining animals were held along with food in a large circulating system under conditions similar to those described above, for periods not exceeding $5 \mathrm{~d}$. The effects of cell concentration and silt load on filtration/respiration rate were investigated in separate experiments, each involving five individuals. Ration levels in the former were between 1.3 and $74.10^{6} \mathrm{D}$. primolecta cells $1^{-1}$. Silt load was simulated by additions of quantities between 10 and $25 \mathrm{mgl} \mathrm{l}^{-1}$ of purified diatomacous earth (E. Merck) to the algae $\left(20.10^{6}\right.$ cells $\left.1^{-1}\right)$. The diatomaceous earth particles ranged in size from 12 to $50 \mu \mathrm{m}$ with the volume peak at $25 \mu \mathrm{m}$. Actively feeding ascidians were exposed to each treatment in random sequence for $8 \mathrm{~h}$, including an equilibration period of $3 \mathrm{~h}$, after which filtration' respiration rates were monitored as described previously. Thus oxygen consumption measurements were made on each specimen at a minimum interval of $8 \mathrm{~h}$. The filtration rate experiments carried out with $D$. primolecta as food suspension were repeated with the following algal food suspensions and compared with each other: Cricospera carterii, Chaetoceros sp., Tetraselmis chuii, Pheodactylum sp. and Pseudoisochrysis paradoxa. The clearance of kelp particles (6 to $40 \mu \mathrm{m}$, peak at $16 \mu \mathrm{m}$ ) by $P$. stolonifera was also studied. The preparation of $3 \mathrm{~d}$ aged kelp fragments is as described in Stuart (1982)

Assimilation. Assimilation efficiency was determined from the organic content of food and faeces according to Conover (1966). This expresses the overall gain of organic material derived from ingested organic matter, including mucus and digestive products secreted by the ascidian. Samples were dried at $70^{\circ} \mathrm{C}$ for $2 \mathrm{~d}$ and ashed at $480^{\circ} \mathrm{C}$ overnight. Weight determinations were made on an electronic microbalance (Mettler ME 30) with a readability of $1 \mu \mathrm{g}$. Ascidians were maintained in a modification of the apparatus shown in Fig. 2, whereby six 101 aquaria were substituted for the test chambers. The flow rates were increased to avoid depletion of food in these aquaria. In the first experiment the relation between body size and assimilation of Dunaliella primolecta or natural food was investigated. From 4 to 8 (depending on size) freshly collected ascidians were placed in each aquarium and supplied with $20.10^{6}$ cells $D$. primolecta $l^{-1}$ for a period of $5 \mathrm{~d}$. During this time faeces were collected at regular $(3 \mathrm{~h})$ intervals. Sequential samples of faeces and of the $D$. primolecta culture of that day were filtered onto preashed and weighed GF C (2.5 cm diam) filters followed by an ammonium formate rinse to remove salts. The total and ash-free weights of samples were obtained as described. Seawater (25 l), collected concurrently with the ascidians, was filtered through a $125 \mu \mathrm{m}$ sieve followed by a $0.45 \mu \mathrm{m}$ Sartorius filter (142 mm diam). The filter was flushed with ammonium formate and subsamples of the residue transferred to crucibles for determinations of dry and ash-free weight of the natural food source. In the second experiment, the effect of $D$. primolecta cell concentration on assimilation efficiency was examined in fresh ascidians. These were of a range of sizes and distributed 5 individuals per aquarium. Ascidians were exposed for $24 \mathrm{~h}$ in random order to the different cell concentration over a total period of 7 d. Each faecal type was recognised by 
adding carmine particles to the aquaria between feeding regimes. These markers showed that gut passage time was approximately $23 \mathrm{~h}$, regardless of ration level. Collection of faeces and food for Conover ratio analysis was as previously described. The comparative assimilation of $D$. primolecta and kelp fragments was studied in the third experiment. Four ascidians were suspended on plastic mesh trays in aquaria containing one of the following diets: $20.10^{6}$ cells $(=2.3 \mathrm{mg}) D$. primolecta $\mathrm{l}^{-1}$; kelp fragments $\left(2.3 \mathrm{mg} \mathrm{l}^{-1}\right.$ ). Material was kept in suspension with strong circulation from submersible pumps and aeration. Suspension density was monitored (Coulter counter) and adjusted during the feeding period. After the animals had been feeding actively for $12 \mathrm{~h}$ the water was siphoned-off and the aquaria connected, without exposing the animals to air, to the recirculating system of fresh seawater containing $D$. primolecta at $20.10^{6}$ cells $1^{-1}$. Faeces and food samples were collected and analysed as previously described. The experiment was repeated on 2 further occasions and in all cases the tests were conducted in duplicate.

Particle selection. Particle-size selection in the range from bacteria $(0.5 \mu \mathrm{m})$ to $20 \mu \mathrm{m}$ by Pyura stolonifera has been described (Stuart and Klumpp, 1984). This work was extended in the present study to examine the upper limit of size selection. Ascidians were fed 1 to $5 \mathrm{~h}$ on (1) kelp fragments ( 6 to $100 \mu \mathrm{m}$ ), (2) Sephadex G-75 beads (20 to $100 \mu \mathrm{m}$ ) and (3) diatomaceous earth $(12$ to $50 \mu \mathrm{m}) ;(2)$ and (3) were in combination with $D$. primolecta. The size distribution for these particulate materials and that in nature is given in Fig. 4 . The different spectra for kelp were obtained by mixing varying proportions of sieved size fractions. Retention efficiency for each sized particle was determined using the indirect method, including blanks and controls to account for production and loss of particles.

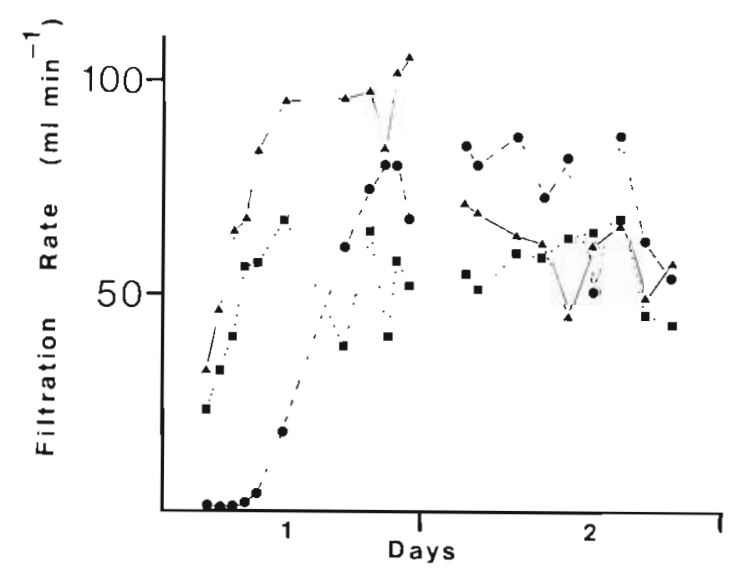

Fig. 3. Pyura stolonifera. Variation in filtration rate from time of collection for 3 individuals. Readings made between 0900 and 1800 h. Food: Dunaliella primolecta
The decline in concentration with time for each particle size was compared in a closed system. Calculation of retention efficiency was as given in Harbison and McAlister (1979). In this method it is assumed that retention efficiency is $100 \%$ for those particles at which maximum clearance or grazing occurs. Using the direct method, in which the particle concentration in inhalent and exhalent waters are compared (Møhlenberg and Riisgård, 1978), it has been confirmed that particles of less than $20 \mu \mathrm{m}$ are retained at $100 \%$ efficiency (Stuart and Klumpp, 1984). The direct method, however, is not suitable for determining the retention of particles in the larger size range since it shows which particles are trapped (on oral tentacles or stigmata) but not necessarily those that are retained and subsequently ingested.

\section{RESULTS}

\section{Feeding}

Long-term monitoring of filtration rate in 3 freshly collected specimens of Pyura stolonifera showed an increasing rate of filtration over a period of $12 \mathrm{~h}$ following the initial disturbance of collection and handling (Fig. 3). A steady-state situation was then reached in which the rate continued to vary about a mean level. These fluctuations did not appear to correspond to any behavioural responses in the ascidians. The few other studies concerning long-term pattern of filtration rate in ascidians report a similar trend (Fiala-Médioni, 1973, 1974, 1978a; Holmes, 1973). Furthermore, these authors and the present study found no discernable rhythm in filtration rate that coincided with environmental conditions. Ascidians collected at the same time as those above, but which had previously been kept for $21 \mathrm{~d}$ in a recirculating aquarium system without the addition of food, were monitored over $7 \mathrm{~d}$. Filtration rate continued to rise during the observation period approaching the same mean level found for the unstarved group.

Many studies on filter feeders have confirmed that filtration rate (FR) is related to body weight (W) according to the allometric equation

$$
\mathrm{FR}=a \mathrm{~W}^{b}
$$

where $a=$ rate for an animal of unit mass $; b=$ slope of the $\log F R / \log W$ plot. The exponential $b$ is usually close to the theoretical value of $2 / 3$ as derived from the squared dimensions of branchial surface and cubed dimensions of body size (see review by Bayne and Newell, 1983). There was a strong positive correlation between filtration rate $\left(\mathrm{ml} \mathrm{min}^{-1}\right)$ and dry tissue weight $(\mathrm{g})$ in all of the 3 populations of Pyura stoloni- 


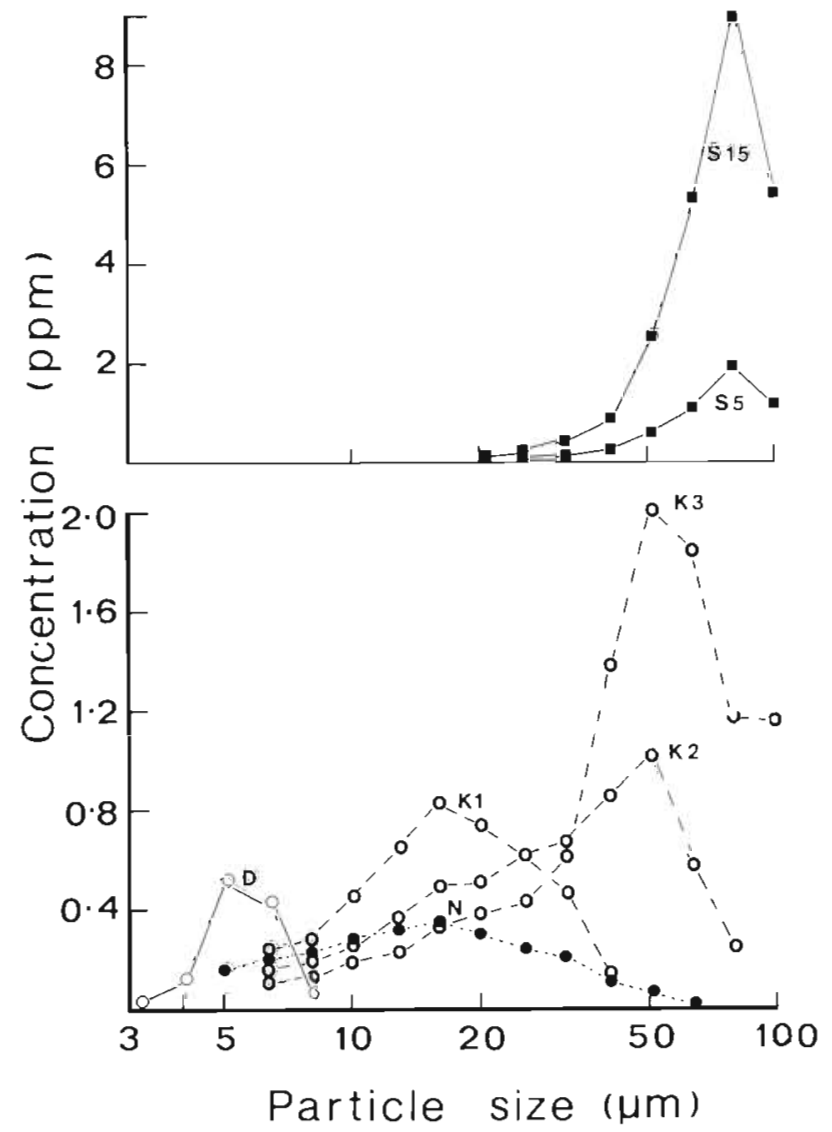

Fig. 4. Particle-size distribution of experimental (D, S, K) and natural (N) suspended material. Natural spectrum is from a sample collected in westcoast kelp beds after rough seas (from Stuart and Klumpp, 1984). D: Dunaliella primolecta; K 1-3: different combinations of sieved kelp fragments; $S_{5}$ \& 15: Sephadex at 5 and $15 \mathrm{mg} \mathrm{l}^{-1}$

fera studied (Fig. 5). The relation in the rocky coast populations from False Bay (Kalk Bay) and the west coast (Blauberg) was indistinguishable and described as: $F R=8.15 W^{0.70}(\mathrm{r}=0.87 ; \mathrm{n}=64)$. The relation between filtration rate and weight for Langebaan ascidians was: $F R=15.63 W^{1.08}(r=0.98 ; n=13)$. In comparison, ascidians from the sand flats of Langebaan lagoon filtered at a faster rate and these differences were more pronounced in larger individuals (increased $b$-value). A comparison of filtration rate in $P$. stolonifera with that of the other species of ascidians studied is made difficult by the differences in technique used by various authors. Nevertheless, it is clear that the filtration rate in $P$. stolonifera is much lower than that for other species from the most comparable studies (Table 1)

The effect of Dunaliella primolecta cell concentration on filtration rate was examined in ascidians of different sizes. The chosen range of cell concentration (0.147 to $8.36 \mathrm{mg} \mathrm{l}^{-1}$, dry weight) covers the observed range of particulate organic matter in the natural environment (Griffiths, 1980b; Cliff, 1982a, b; Stuart, 1982). Filtration rate remained unaffected at cell concentrations from 7 to $74.10^{6}$ cells $1^{-1}$, while at the lower concentrations of 1.3 and $3.10^{6}$ cells $l^{-1}$ there was occasional cessation of filtering and a greater variation in the rate as demonstrated by lower means and increased standard deviation (Table 2). In the total absence of food the ascidian sometimes closed siphons for extended periods. Few have considered the effect of food concentration on feeding rate in ascidians. Even for the well studied bivalve molluscs, there is some disagreement about the relation between food concentration and filtration rate, but there is a consensus that filtration rate is reduced with increasing ration levels, so that ingestion rate remains relatively constant at an optimum level (see review by Bayne and Newell, 1983). High ration levels induce pseudofaeces formation in bivalves, but such a mechanism was not seen in the present study or in earlier investigations on other ascidian species fed pure algal cells. Holmes (1973), without presenting details, stated that cell density had no effect on the filtration rate of the ascidians Styela clava and Ascidiella aspersa. FialaMédoni (1979a) examining filtration rate in Phallusia manmillata at Monochrysis lutheri cell concentrations of 2,20 and $200.10^{6} 1^{-1}$, reported a substantial decline only at the highest ration.

The inclusion of environmentally realistic silt loads of 10 and $25 \mathrm{mg} \mathrm{l}^{-1}$ did not influence the filtration rate of Pyura stolonifera (Table 3). Robbins (1983) studied effects of silt on feeding in ascidians and reported that filtration rate was inversely related to inorganic particle concentration. The method used by Robbins, which was inaccurate below $6 \mathrm{mg} \mathrm{l}^{-1}$ for natural mud and $20 \mathrm{mg} \mathrm{l}^{-1}$ for artificial particles, included silt loads of up to 130 and $400 \mathrm{mg} \mathrm{l}^{-1}$, respectively, to cover potential extremes in turbidity for that region. In the case of $P$. stolonifera, the most turbid habitats for which data are available are in False Bay and along the Natal coast. In these 2 regions the maximum silt loads recorded are, respectively, $135 \mathrm{mg} \mathrm{l}^{-1}$, of which $19 \%$ is in the $<100 \mu \mathrm{m}$ size range (Griffiths, 1980b) and 159 mg $1^{-1}$ (Berry and Schleyer, 1983).

The organic food components available to Pyura stolonifera in nature are mainly detritus formed from macroalgae and phytoplankton cells, especially diatoms (15\% of POM in kelp bed waters: Stuart, 1982). P. stolonifera filtered different phytoplankton species, including those found in the natural environment and kelp fragments (for details see 'Materials and Methods') at equal rates.

Experiments were performed on the retention of different sized particles by Pyura stolonifera, including the size spectrum normally encounted in the waters of 


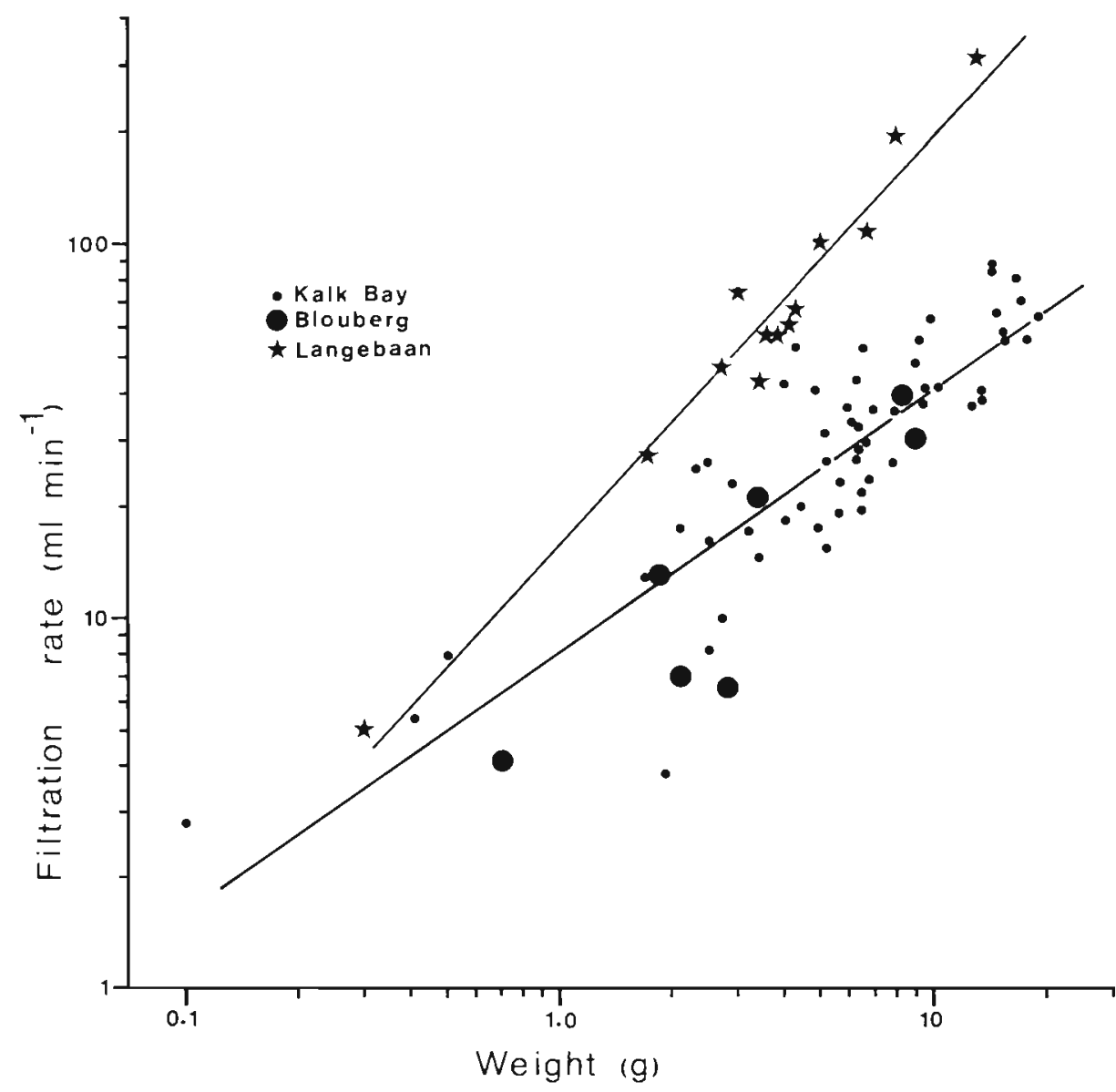

Fig. 5. Pyura stolonifera. Filtration rates as function of body size in 3 populations. Regression lines for log transformed data are shown.

Food: Dunaliella primolecta the S.W. Cape (Fig. 4 and Table 4). Kelp particles, at concentrations from 1 to $22 \mathrm{mg} \mathrm{l}^{-1}$ and covering the size range of 6 to $100 \mu \mathrm{m}$, were retained at around $100 \%$ efficiency. Sephadex particles (20 to $100 \mu \mathrm{m}$ ), up to a concentration of $5 \mathrm{mg} \mathrm{l}^{-1}$, were similarly retained but at concentrations of $15 \mathrm{mg} \mathrm{l}^{-1}$ and higher, 'backsquirting' occurred where the ascidian closed its inhalent siphon at regular intervals of approximately $7 \mathrm{~min}$ and ejected separate particles (= pseudofaeces) through the exhalent siphon with a sudden contraction of the body. Such behaviour in ascidians was described by McGinitie (1939) as a reaction to large or foreign particles. Particles in the size range of 65 to $100 \mu \mathrm{m}$ were retained at low to zero efficiency under these circumstances (Table 4 ). With sequential addition of diatomaceous earth or kelp particles of type K3 (Fig. 4), the same reaction could be induced at approximately $25 \mathrm{mg} \mathrm{l}^{-1}$ and $50 \mathrm{mg} \mathrm{l}^{-1}$, respectively. Unfortunately counting of different sized particles was not possible in these latter cases. There was a gradual constriction of the inhalent aperture with increasing load of Sephadex and this may result in closing of the tentacles of the oral funnel. Using the direct method of comparing inhalent and exhalent waters it was observed that suspensions of particles larger than 20 to $25 \mu \mathrm{m}$ were always nearly completely retained, presumably by the mesh of stigmata which have an estimated width of 30 to $37 \mu \mathrm{m}$. Disturbed animals displayed a low retention $(3 \%)$ of the smaller particles, but this gradually increased to $100 \%$ as the animal reformed the mucous mesh

\section{Respiration}

The relation between respiration rate (R) in $\mathrm{ml}$ $\mathrm{O}_{2} \min ^{-1}$ and body size (W) in g dry wt in Pyura stolonifera (Fig. 6) from rocky shores is described by the allometric equation: $R=0.14 \mathrm{~W}^{0.95}(\mathrm{r}=0.91$; $\mathrm{n}=75$ ). The population in Langebaan lagoon respired at a rate that was not significantly different ( $\mathrm{t}$ test: $\mathrm{t}=$ $0.332 ; \quad P=0.740$ ) to that of the rocky shore group Oxygen consumption rates in other ascidian species are $0.592 \mathrm{ml} \mathrm{h}^{-1} \mathrm{~g}^{-1}\left(15^{\circ} \mathrm{C}\right)$ in Phallusia mammalata (Fiala-Médoni, $1979 \mathrm{~b}), 0.300 \mathrm{ml} \mathrm{h}^{-1} \mathrm{~g}^{-1}\left(15^{\circ} \mathrm{C}\right)$ in Styela plicata (Fisher, 1976) and $0.234 \mathrm{ml} \mathrm{h}^{-1} \mathrm{~g}^{-1}\left(15^{\circ} \mathrm{C}\right)$ in Ciona intestinalis (Burky and Farmanfarmaian, 1965). Among these authors, only Fisher examined oxygen consumption as a function of size and found an 
Table 1. Comparison of filtration rate (FR) of ascidians as determined by recent studies

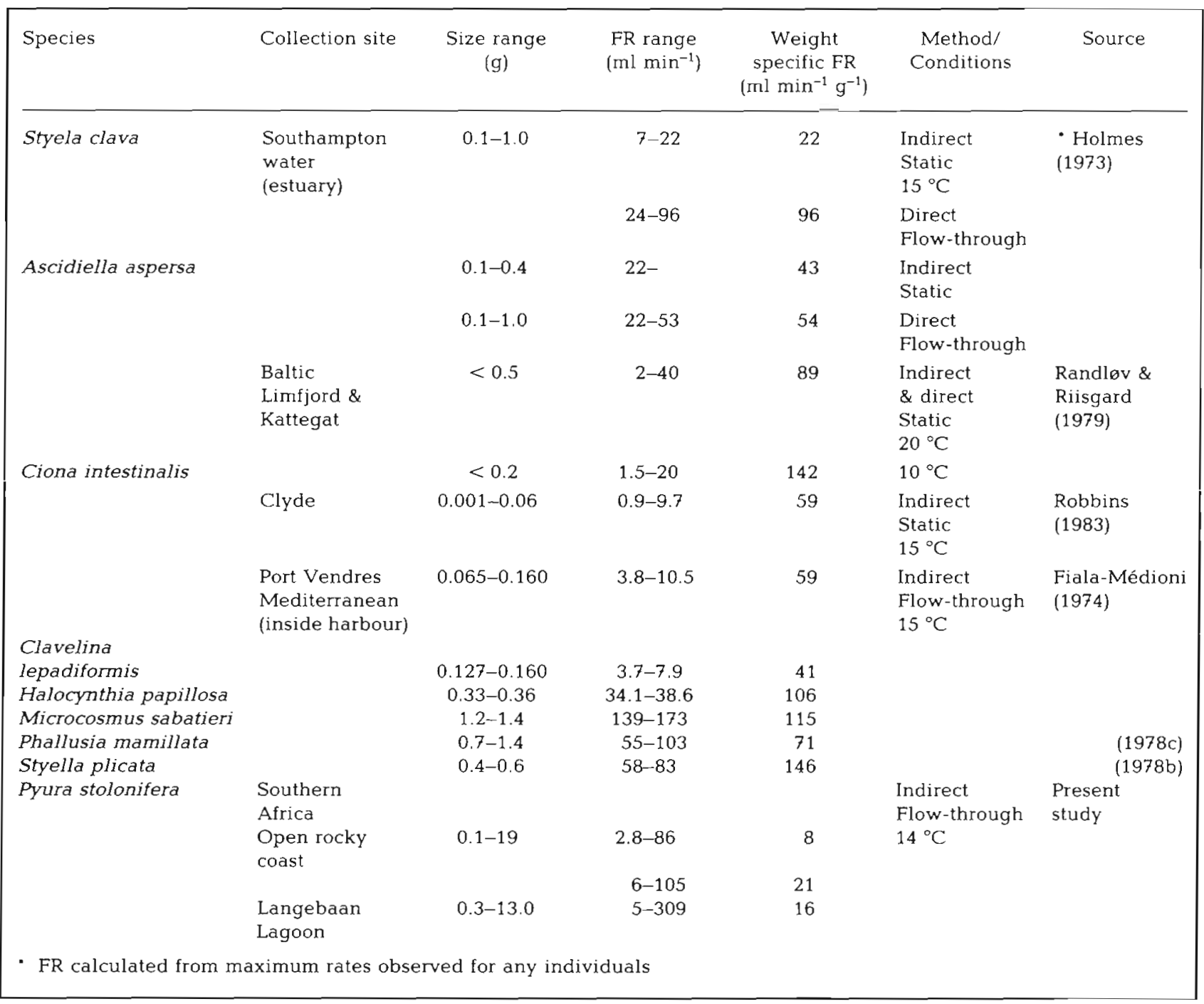

average $b$ value of 0.7 . Jørgensen (1952) obtained a respiration rate of 0.6 to $0.9 \mathrm{ml} \mathrm{h}^{-1}$ for C. intestinalis of unspecified mass and calculated the physiologically important ratio of water transport to metabolic rate; this being 10 to $20 \mathrm{l} \mathrm{ml}^{-1}$ oxygen uptake in ascidians (C. intestinalis and Molgula manhattensis) and bivalves. Fiala-Médioni in her study of $P$. mammalata, reports a ratio of 10 . A similar calculation for $P$. stolonifera of $1 \mathrm{~g}$ tissue dry weight gives $3.5 \mathrm{I} \mathrm{ml}^{-1} \mathrm{O}_{2}$ for rocky coast animals and $3.71 \mathrm{ml}^{-1} \mathrm{O}_{2}$ in those from Langebaan and shows that this species is by comparison less efficient. The efficiency with which oxygen in the water is utilised by $P$. stolonifera is low at $5 \%$.

Respiration rate was unaffected by different concentrations of Dunaliella primolecta of between zero ration and $50.10^{6}$ cells $1^{-1}$ (Table 5). Research on bivalve molluscs shows there is a trend of increased oxygen consumption with increased ration (Griffiths and King, 1979) but comparable data for ascidians are not available. Although it is possible that the $8 \mathrm{~h}$ acclimation period for examining respiratory response at each ration level may have been insufficient, it appears that the feeding process, which slowed down at low cell concentration (Table 2), is independent of gas exchange or ventilation rate in Pyura stolonifera.

\section{Assimilation}

Pyura stolonifera assimilated Dunaliella primolecta cells at $75 \pm 10 \%$ efficiency and this was independent of ascidian body weight (Fig. 7). Fiala-Médioni (1973; 1974) reports assimilation efficiencies ranging from 83 to $93 \%$ in several other ascidian species fed on the alga Monochrysis lutheri. Comparison of natural food and faeces in the same group of animals gave an 
Table 2. Pyura stolonifera. Effect of algal cell concentration and ascidians (from Kalk Bay) body size on filtration rate. Data expressed as means and standard deviation for 5 replicates

\begin{tabular}{|cccccc|}
\hline $\begin{array}{c}\text { Dunaliella } \\
\text { primolecta } \\
\text { cell con- } \\
\text { centration } \\
\left(\mathrm{x} 10^{6} \mathrm{l}^{-1}\right)\end{array}$ & 1 & 2 & 3 & 4 & 5 \\
\hline 1.3 & 12.0 & 26.3 & 24.5 & 42.7 & 38.0 \\
& $(11.8)$ & $(20.5)$ & $(8.9)$ & $(32.3)$ & $(4.6)$ \\
3.0 & 18.1 & 37.9 & 20.7 & 45.0 & 21.0 \\
& $(3.9)$ & $(12.6)$ & $(11.3)$ & $(26.0)$ & $(12.5)$ \\
7.0 & 17.2 & 51.5 & 24.8 & 70.6 & 31.1 \\
& $(4.0)$ & $(5.8)$ & $(5.1)$ & $(2.2)$ & $(6.7)$ \\
12.0 & 18.3 & 56.6 & 28.3 & 70.3 & 32.3 \\
& $(5.8)$ & $(2.5)$ & $(3.3)$ & $(4.5)$ & $(6.9)$ \\
26.0 & 17.2 & 50.2 & 26.2 & 67.5 & 33.1 \\
& $(3.5)$ & $(4.6)$ & $(4.4)$ & $(2.6)$ & $(4.3)$ \\
48.0 & 18.7 & 52.9 & 28.4 & 65.8 & 32.0 \\
74.0 & $(1.4)$ & $(6.4)$ & $(1.0)$ & $(1.9)$ & $(2.1)$ \\
& 16.8 & 46.9 & 32.3 & 71.4 & 25.8 \\
Individual & $(1.8)$ & $(4.0)$ & $(3.6)$ & $(9.7)$ & $(5.3)$ \\
Dry tissue & & & & & \\
weight (g) & 3.2 & 16.1 & 6.5 & 23.7 & 5.7 \\
\hline
\end{tabular}

average assimilation efficiency of $34 \pm 13 \%$, and in this case there was a clear trend of increasing efficiency with size (Fig. 7). Faeces derived from natural food comprised compact pellets of unidentifiable debris, diatom frustules, and considerable amounts of sand. The utilization of natural food by $P$. stolonifera is similar to that of mussels (40\% AE) in False Bay
Table 3. Pyura stolonifera. Effect of silt load on filtration rate in ascidians from Kalk Bay. Means and standard deviation $(\mathrm{n}=4)$. Rate in $\mathrm{ml} \mathrm{min}^{-1}$. Cells are Dunaliella primolecta

\begin{tabular}{|c|c|c|c|c|}
\hline \multirow[t]{2}{*}{ Treatment } & \multicolumn{4}{|c|}{ Individual } \\
\hline & 1 & 2 & 3 & 4 \\
\hline Control & & & & \\
\hline $20 \times 10^{6}$ cells $l^{-1}$ & $16.9(2.1)$ & $20.3(2.3)$ & $19.3(5.3)$ & $26.2(2.3)$ \\
\hline $\begin{array}{l}20 \times 10^{6} \mathrm{cells}^{-1} \\
\left(\text { silt }: 10 \mathrm{mg} \mathrm{l}^{-1}\right)\end{array}$ & $19.8(3.5)$ & $19.1(2.0)$ & $21.4(1.4)$ & $29.8(2.2)$ \\
\hline $\begin{array}{l}\left.20 \times 10^{6} \text { cells }\right)^{-1} \\
\text { (silt: } 25 \mathrm{mg} \mathrm{l}^{-1} \text { ) }\end{array}$ & $22.0(3.0)$ & $19.7(2.5)$ & $17.0(0.7)$ & $22.3(1.7)$ \\
\hline
\end{tabular}

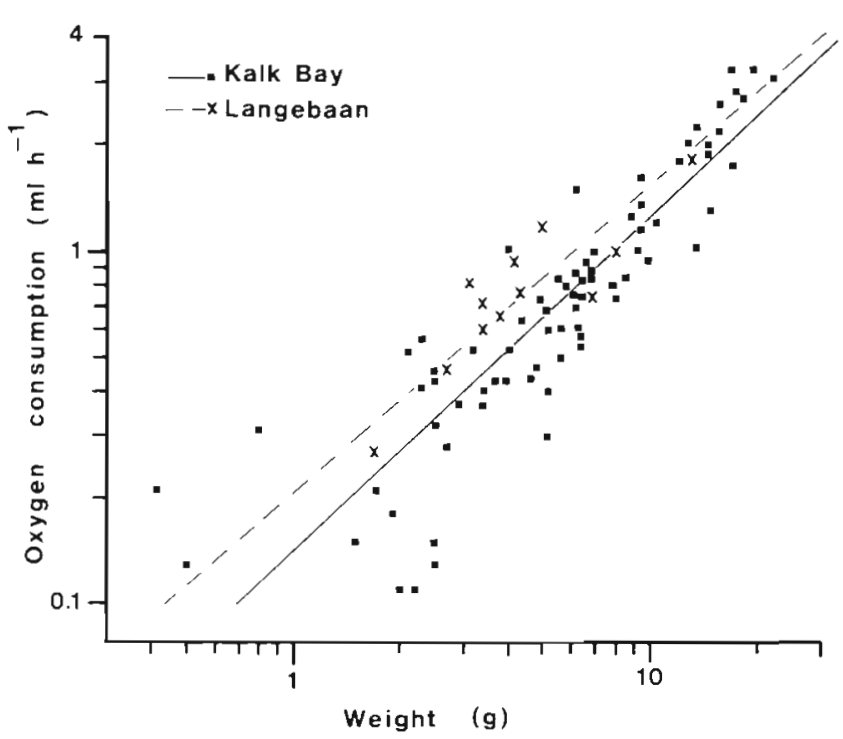

Fig. 6. Pyura stolonifera. Respiration rate in 2 populations as a function of body size. Regression lines for log transformed data are shown

Table 4. Pyura stolonifera. Retention efficiency for different sized particles of kelp, diatomaceous earth and Sephadex. Size spectrum for these suspensions given in Fig. 4

\begin{tabular}{|c|c|c|c|c|c|c|c|c|c|c|c|c|c|}
\hline \multirow[t]{2}{*}{ Suspended sample } & \multicolumn{13}{|c|}{ Mean particle size $(\mu \mathrm{m})$} \\
\hline & 6.35 & 8.00 & 10.08 & 12.7 & 16.0 & 20.2 & 25.4 & 32.0 & 40.3 & 50.8 & 64.0 & 80.6 & 101 \\
\hline $\begin{array}{l}\text { Kelp } 1 \\
\text { at } 14 \mathrm{mg} \mathrm{l}^{-1}\end{array}$ & 85.8 & 88.5 & 89.1 & 90.9 & 90.6 & 100 & 97.7 & 86.9 & 92.4 & & & & \\
\hline $\begin{array}{l}\text { Kelp } 2 \\
\text { at } 19 \mathrm{mg} \mathrm{l}^{-1}\end{array}$ & 83.1 & 84.4 & 90.6 & 84.4 & 81.2 & 93.7 & 90.6 & 93.7 & 100 & 84.4 & 78.1 & & \\
\hline $\begin{array}{l}\text { Kelp } 3 \\
\text { at } 32 \mathrm{mg} \mathrm{l}^{-1}\end{array}$ & 81.5 & 82.7 & 79.5 & 89.7 & 94.9 & 100 & 87.2 & 84.6 & 97.4 & 92.3 & 92.3 & 87.2 & 89.7 \\
\hline $\begin{array}{l}\text { - Diatomaceous earth } \\
\text { at } 5 \mathrm{mg} \mathrm{l}^{-1}\end{array}$ & 82.3 & 77.5 & 93.1 & 100 & 93.1 & 89.6 & 86.2 & 93.1 & 100 & & & & \\
\hline $\begin{array}{l}\text { Sephadex } \\
\text { at } 5 \mathrm{mg} \mathrm{l}^{-1}\end{array}$ & 92.0 & 90.4 & & & & & & 96.1 & 75.0 & 100 & 100 & 78.8 & 94.2 \\
\hline $\begin{array}{l}\cdot \text { Sephadex } \\
\text { at } 15 \mathrm{mg} \mathrm{l}^{-1}\end{array}$ & 82.0 & 84.0 & & & & & & 92.0 & 100 & 65.6 & 15.1 & 4.0 & 0 \\
\hline $\begin{array}{l}\text { - Sephadex } \\
\text { at } 25 \mathrm{mg} \mathrm{l}^{-1}\end{array}$ & 86.1 & 89.9 & & & & & & 100 & 41.1 & 73.5 & 0 & 0 & 0 \\
\hline
\end{tabular}




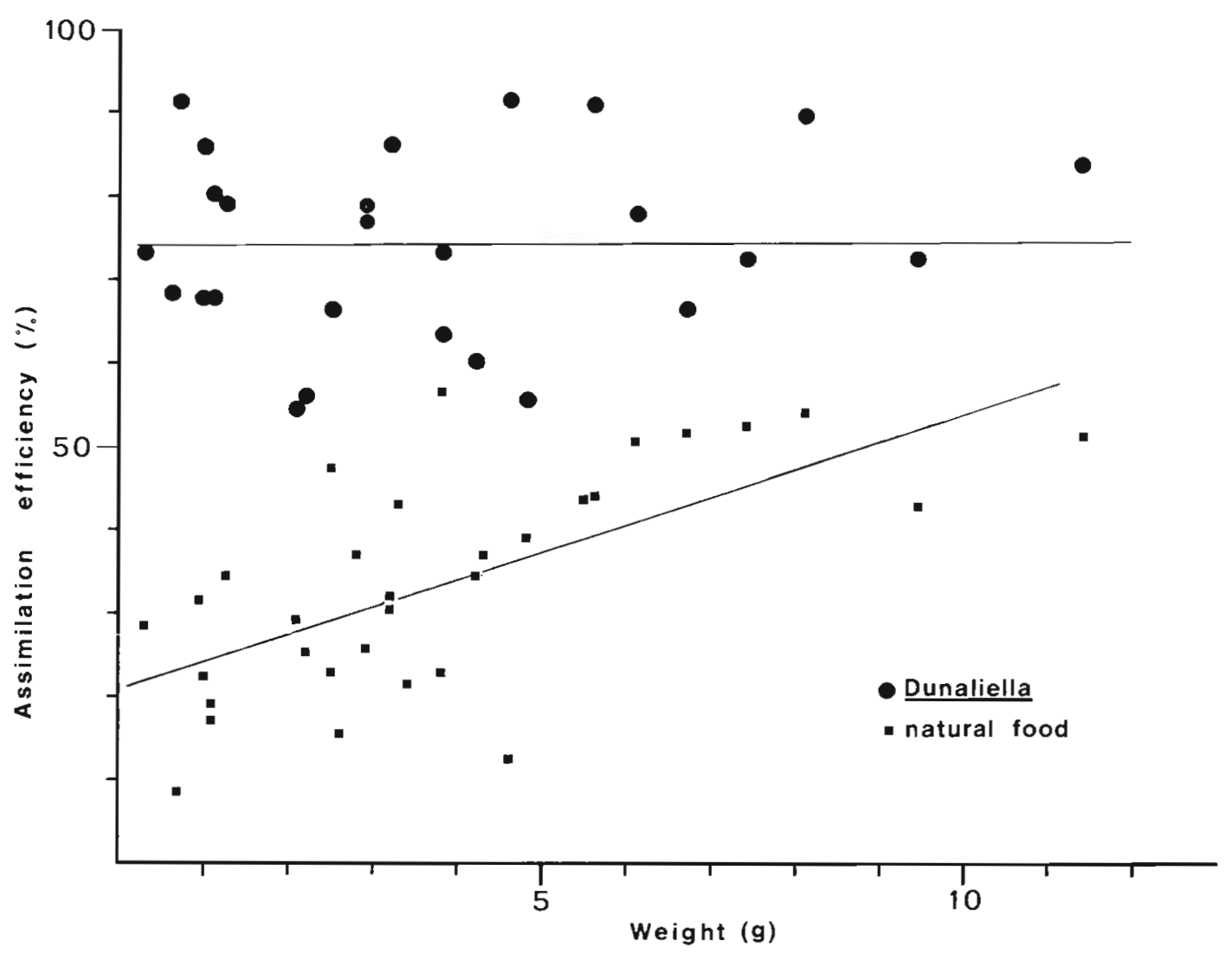

Fig. 7. Pyura stolonifera. Assimilation efficiency in individuals consuming phytoplankton culture (Dunaliella primolecta) or natural food as a function of body size. Regression lines shown

Table 5. Pyura stolonifera. Effects of cell concentration and body size on respiration rate in ascidians from Kalk Bay. Data are means of 5 replicates. Respiration in $\mathrm{ml}$ indiv ${ }^{-1} \mathrm{~h}^{-1}$

\begin{tabular}{|cccccc|}
\hline $\begin{array}{c}\text { Dunaliella } \\
\text { primolecta } \\
\text { cell con- }\end{array}$ & & \multicolumn{5}{c}{ Individual } \\
$\begin{array}{c}\text { centration } \\
\left(\mathrm{x} 10^{6} \mathrm{l}^{-1}\right)\end{array}$ & 1 & 2 & 3 & 4 & 5 \\
\hline No food & 0.64 & 1.05 & 0.47 & 0.31 & 0.31 \\
1.0 & 0.62 & 1.01 & 0.56 & 0.37 & 0.33 \\
3.0 & 0.64 & 1.01 & 0.53 & 0.43 & 0.35 \\
6.0 & 0.62 & 0.95 & 0.56 & 0.37 & 0.29 \\
12.0 & 0.71 & 1.11 & 0.57 & 0.40 & 0.35 \\
24.0 & 0.62 & 1.12 & 0.49 & 0.38 & 0.35 \\
50.0 & 0.58 & 0.93 & 0.51 & 0.38 & 0.27 \\
Dry tissue & & & & & \\
weight (g) & 5.2 & 9.5 & 4.2 & 2.1 & 1.8 \\
\hline
\end{tabular}

(Griffiths, 1980b). The relation between natural-food assimilation efficiency (AE) and tissue dry weight (W) is described by the regression: $\mathrm{AE}=21.1+3.3 \mathrm{~W}$; $\mathrm{r}=$ $0.665, \mathrm{n}=32$.

Assimilation efficiency was independent of
Dunaliella primolecta cell concentration from 1.0 to

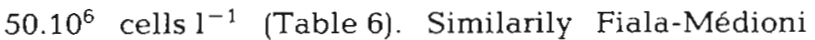
(1979a) found in Phallussia mammalata no effect at cell concentrations of 2 and $20.10^{6}$ Monochrysis lutheri cells $1^{-1}$, but at $200.10^{6}$ cells $l^{-1}$ the assimilation efficiency was depressed to $15 \%$.

Table 6. Pyura stolonifera. Effect of algal cell concentration (Dunaliella primolecta) and body size of ascidians (from Kalk Bay) on assimilation efficiency. Data are means of 5 groups each, with 3 replicates. There were 5 individuals in each group

\begin{tabular}{|ccccc|}
\hline $\begin{array}{c}\text { Dunaliella } \\
\text { primolecta } \\
\text { cell con- } \\
\text { centration } \\
\left(\times 10^{6} \mathrm{I}^{-1}\right)\end{array}$ & 1 & 2 & 3 & 4 \\
\hline 1.0 & 77.6 & 66.9 & 63.8 & 53.8 \\
2.0 & 59.0 & 66.7 & 66.4 & 71.5 \\
5.0 & 70.9 & 63.0 & 70.0 & 64.0 \\
10.0 & 71.9 & 74.1 & 75.4 & 62.2 \\
$30-50.0$ & 70.5 & 67.5 & 62.0 & 62.6 \\
$\begin{array}{c}\text { Average dry } \\
\text { tissue weight (g) }\end{array}$ & 14 & 12.2 & 4.8 & 2.3 \\
\hline
\end{tabular}


Of the kelp fragments of type $\mathrm{K}_{1}, 2.3 \mathrm{mg} \mathrm{l}^{-1}$ (Fig. 4) were assimilated by Pyura stolonifera at $42 \pm 4 \%$ $(n=6)$ efficiency. This compares with $50 \%$ efficiency reported by Stuart et al. (1982) for the mussel Aulacomya ater consuming the same type of kelp fragments.

\section{Energy balance}

Net energy balance is the energy available for production (somatic and reproductive) and is the difference between respiratory energy costs and the assimilated energy. Energy balance in Pyura stolonifera of standard $1 \mathrm{~g}$ tissue dry weight, fed Dunaliella primolecta cells, is calculated from summarised data on feeding, respiration and assimilation (Table 7 ; Fig. 8). Since filtration and respiration rates and assimilation efficiency in $P$. stolonifera of a range of body sizes are generally independent of food concentration (Tables 2, 5 and 6), both ingested and assimilated ration increase in direct proportion to food concentration while metabolic energy costs are constant. Thus net energy balance increases linearly with food concentration and is positive at concentrations greater than $4.10^{6}$ cells $1^{-1}\left(=0.4 \mathrm{mg} \mathrm{l}^{-1}\right)$. Furthermore, feeding rate is related to the power of body weight (Fig. 5) and respiratory energy costs as a proportion of assimilated energy is greater in large than in small individuals $(4.6 \%$ at $1 \mathrm{~g} ; 11 \%$ at $20 \mathrm{~g})$. For these reasons, net energy balance as a percentage of body energy content per day plotted against food concentration declines with increasing size of $P$. stolonifera (Fig. 9a). Similarly, net growth efficiency $\mathrm{K}_{2}$ (net energy balance as a proportion of energy assimilated in organic matter) plotted against assimilated ration (Fig. 9b) approaches the asymptotic level of 0.95 at lower rations in small animals than in larger ones.

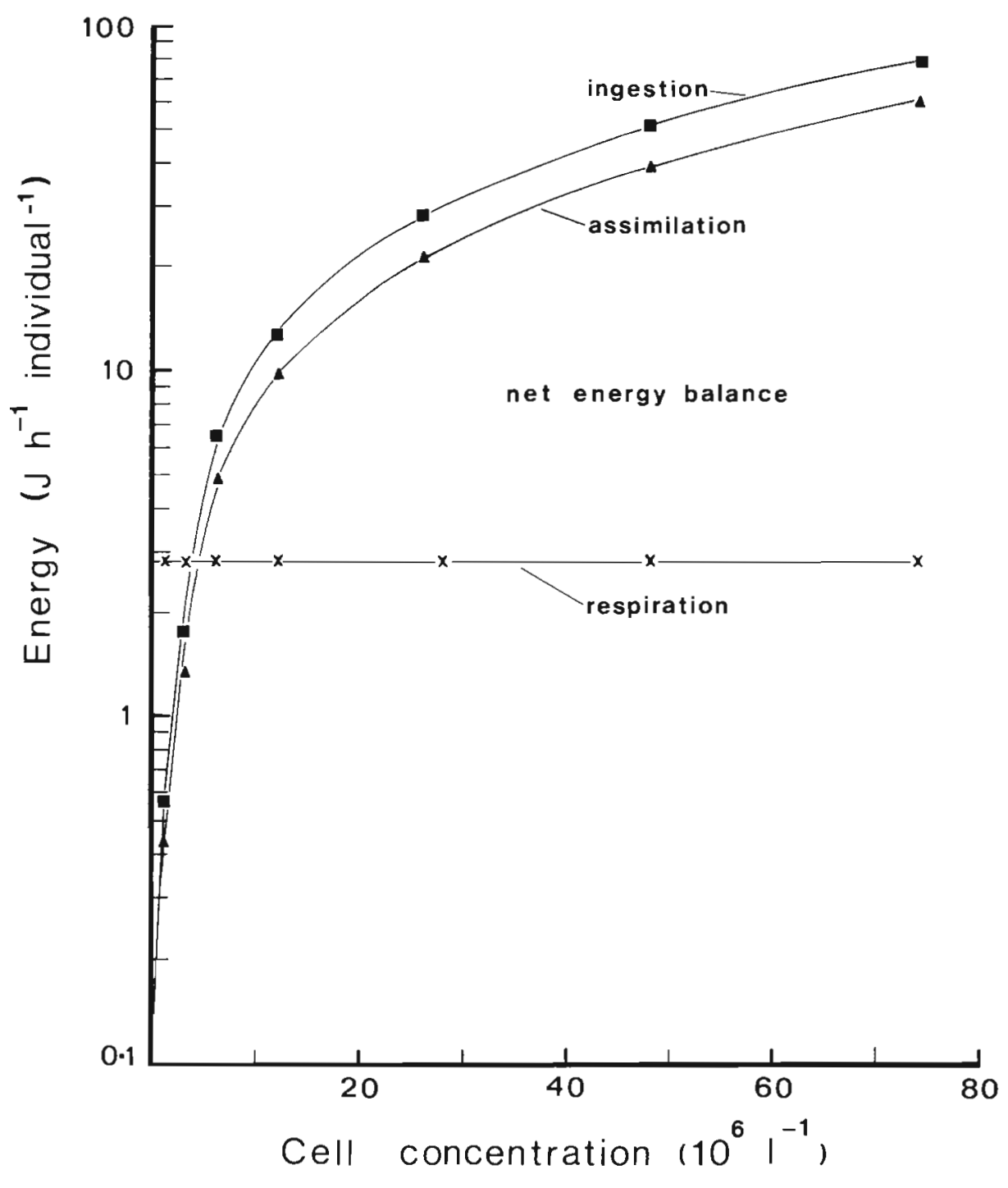

Fig. 8. Pyura stolonifera. Energy content of ingestion ration, assimilation ration, respiration and net energy balance in individuals of $1 \mathrm{~g}$ tissue dry weight, related to concentration of Dunaliella primolecta 


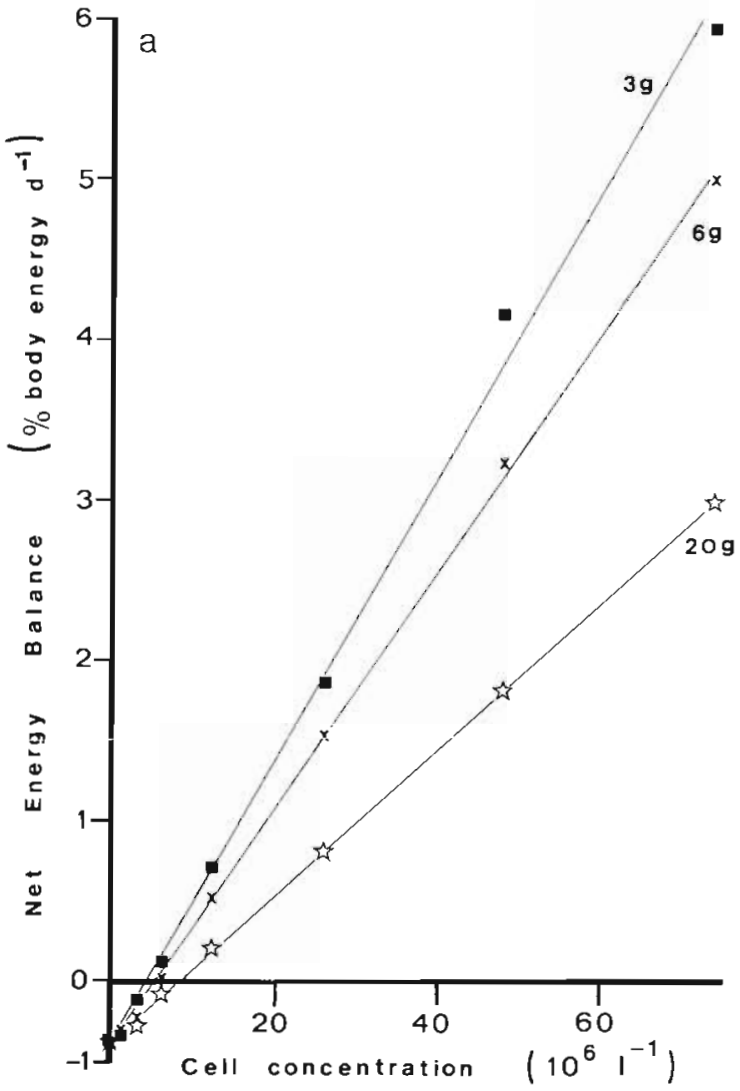

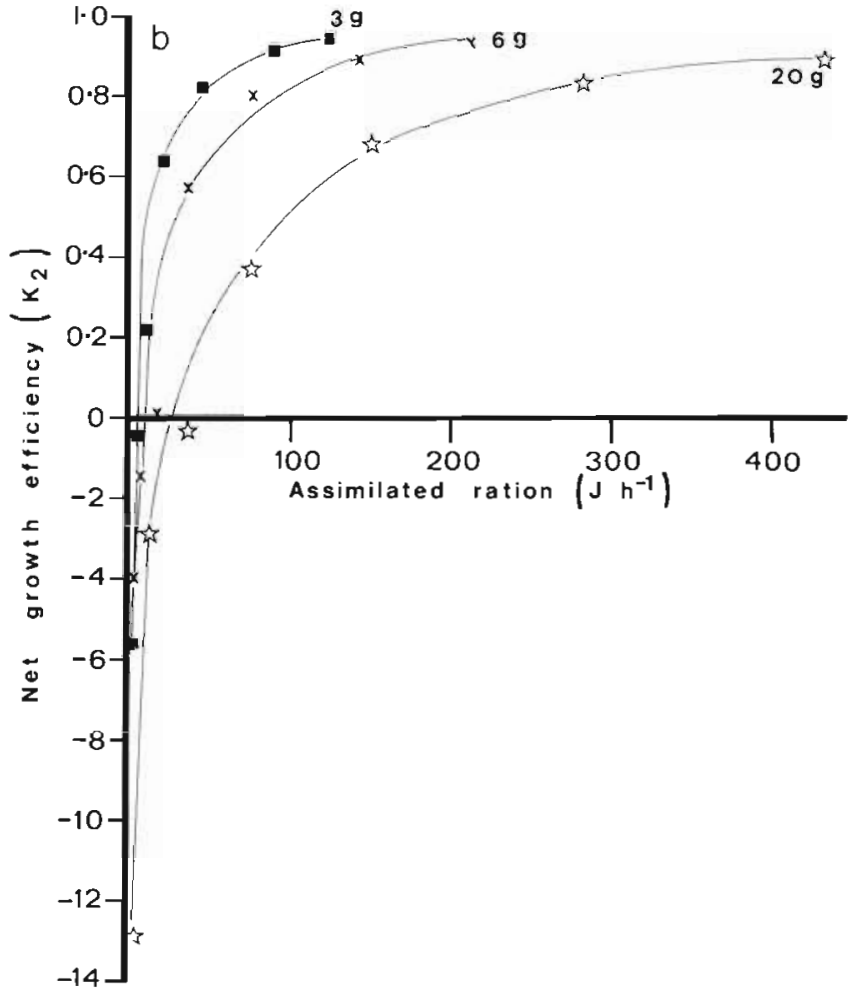

Fig. 9. Pyura stolonifera. (a) Net energy balance as function of food concentration; (b) net growth efficiency $\left(\mathrm{K}_{2}\right)$ as function of assimilated ration for 3 different ascidian weights (food: Dunaliella primolecta)

\section{DISCUSSION}

The concept of energy balance as derived previously for a diet of Dunaliella primolecta can be re-examined in the light of our knowledge of the response of Pyura stolonifera to its natural environment. Phytoplankton cells, such as diatoms and dinoflagellates which occur normally as a minor component in the coastal waters of the south-west Cape, but may be of considerable importance following upwelling (Field et al., 1980b; Wulff and Field, 1983), are ingested by $P$. stolonifera at a rate equal to that of $D$. primolecta. The main food source to $P$. stolonifera and other Cape filter feeders is detritus comprising decomposed macroalgae and faeces (Griffiths, 1980b; Stuart, 1982), aged kelp fragments as used in the present study approximate the composition of natural suspended particulate matter (Stuart, 1982). Food particles (organic matter) of the natural size spectrum, of which $80 \%$ by volume are less than $20 \mu \mathrm{m}$ diameter (Stuart and Klumpp, 1984), and at natural densities ( 1 to $7 \mathrm{mg} \mathrm{l^{-1 }}$ ), are ingested at equal rates and $100 \%$ efficiency by $P$. stolonifera (Stuart and Klumpp, 1984; Table 4). $P$, stolonifera assimilates kelp detritus at an efficiency of $40 \%$ which compares with $50 \%$ and $40 \%$ in mussels Aulacomya ater (Stuart et al., 1982) and Choromytilus meridionalis (Griffiths, 1980b), respectively. D. primolecta was assimilated at $75 \%$ in the ascidian and maximum rates of this order apply for the 2 mussels. No evidence for an effect of food concentration on assimilation efficiency was observed in $P$. stolonifera fed $D$. primolecta (Table 6), and it is assumed the same applies for equivalent rations in nature.

Silt is a variable and important component of the suspended matter in the environment of Pyura stolonifera. On average, the waters of False Bay contain $21 \mathrm{mg} \mathrm{l}^{-1}$ inorganic matter, of which some $73 \%$ of particles are larger than $100 \mu \mathrm{m}$, and this is mainly in the form of sand grains (Griffiths, 1980b). Much lower silt levels are found in kelp bed waters ( 1 to $5 \mathrm{mg} \mathrm{l}^{-1}$ ) where most particles are smaller than $100 \mu \mathrm{m}$ (Field et al., 1980b; Stuart, 1982). Silt at these natural densities does not affect the rate at which $P$. stolonifera ingests food particles (Table 3 ) or silt (Table 4). There is evidence that $P$. Stolonifera is able to reject large silt particles $(>65 \mu \mathrm{m})$, probably with the aid of its oral tentacles, at particle densities observed in waters of False Bay (Table 4). The 'back-squirting' behaviour in 
$P$. stolonifera, as demonstrated in the laboratory under conditions of large particle size and high density, was also observed in the field at False Bay (unpubl. own data). Millar (1960) provided evidence for selective feeding in ascidians when he observed that the branchial sac contained a mixture of sand and phytoplankton, but only phytoplankton cells were passed into the gut. Also McGinitie (1939) and Werner and Werner (1954) report that ascidians of a wide range of types can reject 'foreign' particles. It seems that the sorting and rejection takes place at two levels; very large particles are screened by the tentacular ring (McGinitie, 1939; Werner and Werner, 1954; present study) and those that pass this barrier are dealt with by specialised cilia lining the dorsal groove (McGinitie, 1939). However, more convincing proof is required to show that the latter occurs. Some silt is ingested and appears along with digested food particles in the faeces of $P$. stolonifera when these are fed a mixture of algae and silt (unpubl. own data) and invariably in natural faeces of ascidians collected at False Bay (results pertaining to Fig. 7). The close approximation of field estimates on assimilation of organic matter in natural seston, which includes silt (Fig. 7; Griffiths, $1980 \mathrm{~b}$ ) with that of 'natural-type' kelp fragments (Stuart 1982; present study) indicates that silt ingested by ascidians and mussels of SW Cape waters does not affect assimilation of food by these animals in nature.

Using the data of Stuart (1982) on suspended particulate matter in kelp-bed waters, and assuming an assimilation efficiency of $40 \%$ in nature, it is possible to estimate the utilization of energy by Pyura stolonifera under natural conditions. Stuart reported $3.28 \pm$
$2.40 \mathrm{mg} \mathrm{l}^{-1}$ total particulate matter with an energy content of $6.04 \mathrm{~J} \mathrm{mg}^{-1}$ or $19.8 \mathrm{~J} \mathrm{l}^{-1}$, which corresponds to $34 \%$ of the energy per unit mass in Dunaliella primolecta culture. Three organic seston levels, equivalent to the mean and 1 standard deviation reported by Stuart, are used to calculate net energy balance in $P$. stolonifera (Table 7). The overall comparison shows that energy balance based on cultured microalgae is an overestimation of a natural situation. At the lower natural seston level there is a negative energy balance that is equivalent to the daily loss of $0.27 \%$ of body energy. However, at a seston level that corresponds to the average conditions in nature, $P$. stolonifera is able to cover maintenance energy costs and some $27 \%$ of assimilated energy is available for growth and reproduction. Included in Table 7 is the calculation of energy balance and $\mathrm{K}_{2}$ for $P$. stolonifera consuming kelp fragments (energy content: $9.7 \mathrm{~J} \mathrm{mg}^{-1}$ ) for the purpose of comparing energy utilization with the mussel $A$. ater, the dominant filter feeder of West Coast waters (see Stuart, 1982). The ascidian of unit weight has a filtration rate of $0.491 \mathrm{~h}^{-1}$, compared with $1.6 \mathrm{l} \mathrm{h}^{-1}$ in the mussel and the corresponding respiration rates are 0.14 and $0.31 \mathrm{ml} \mathrm{O}_{2} \mathrm{~h}^{-1}$. The mussel therefore ingests $46.5 \mathrm{~J} \mathrm{~h}^{-1}$ and assimilates $23.3 \mathrm{~J} \mathrm{~h}^{-1}$, which results in a net energy balance of $17.2 \mathrm{~J} \mathrm{~h}^{-1}$ $\left(\mathrm{K}_{2}=0.74\right)$. In comparison, P. stolonifera ingests $14.3 \mathrm{~J}$ $\mathrm{h}^{-1}$, of which $5.7 \mathrm{~J} \mathrm{~h}^{-1}$ is assimilated to give an energy balance of $2.9 \mathrm{~J} \mathrm{~h}^{-1}\left(\mathrm{~K}_{2}=0.50\right)$. Stuart predicted that energy balance in Aulacomya ater fed kelp fragments continues to rise with ration, and growth efficiency when plotted against assimilated ration - approaches an asymptote. Both the ascidian and the mussel would

Table 7. Pyura stolonifera. Data for calculation of net energy balance of $1 \mathrm{~g}$ tissue dry weight sustained on Dunaliella primolecta, kelp fragments and natural suspended matter (data on natural ration amount and energy content from Stuart, 1982. FR: Filtration rate; R: respiration rate; $\mathrm{I}$ : ingested ration; AE: assimilation efficiency; A: assimilated ration. Energy conversion factors were: $10^{6}$

D. primolecta cells $=0.113 \mathrm{dry} w \mathrm{wt}=2.20 \mathrm{~J} ; P$. stolonifera flesh $=15.58 \mathrm{kJg}^{-1} ; 1 \mathrm{ml} \mathrm{O}_{2}=20.0 \mathrm{~J}$ (from Winberg, 1956)

\begin{tabular}{|c|c|c|c|c|c|c|c|c|c|c|c|}
\hline \multicolumn{3}{|c|}{$\begin{array}{l}\text { Food type and concentration } \\
\text { D. primolecta }\end{array}$} & \multirow{2}{*}{$\begin{array}{l}\mathrm{FR} \\
\mathrm{lh}^{-1}\end{array}$} & \multirow{2}{*}{$\begin{array}{c}\mathrm{I} \\
\mathrm{Jh}^{-1}\end{array}$} & \multirow{2}{*}{$\begin{array}{l}\mathrm{AE} \\
\%\end{array}$} & \multirow{2}{*}{$\begin{array}{c}\mathrm{A} \\
\mathrm{Jh}^{-1}\end{array}$} & \multirow{2}{*}{$\begin{array}{c}\mathrm{R} \\
\mathrm{Jh}^{-1}\end{array}$} & \multicolumn{2}{|c|}{ Net energy balance } & \multicolumn{2}{|c|}{ Growth efficiency } \\
\hline$\left(10^{6}\right.$ cells $\left.1^{-1}\right)$ & $\mathrm{mg} \mathrm{l}^{-1}$ & $\mathrm{Jl}^{-1}$ & & & & & & $\mathrm{Jh}^{-1}$ & $\%$ day $^{-1}$ & K 1 & $\mathrm{~K} 2$ \\
\hline 0 & 0 & 0 & - & - & - & - & 2.83 & -2.83 & -0.44 & - & - \\
\hline 1.0 & 0.11 & 2.20 & 0.26 & 0.57 & 75 & 0.43 & 2.83 & -2.40 & -0.37 & -4.21 & -5.55 \\
\hline 3.0 & 0.34 & 6.59 & 0.27 & 1.78 & 75 & 1.33 & 2.83 & -1.50 & -0.61 & -0.84 & -1.13 \\
\hline 6.0 & 0.68 & 13.19 & 0.49 & 6.46 & 75 & 4.84 & 2.83 & +2.01 & +0.31 & +0.31 & +0.41 \\
\hline 12.0 & 1.36 & 26.38 & 0.49 & 12.92 & 75 & 9.69 & 2.83 & +6.86 & +1.06 & +0.53 & +0.71 \\
\hline 26.0 & 2.94 & 57.15 & 0.49 & 28.00 & 75 & 21.00 & 2.83 & +18.17 & +2.80 & +0.65 & +0.86 \\
\hline 48.0 & 5.42 & 105.50 & 0.49 & 51.69 & 75 & 38.77 & 2.83 & +35.94 & +5.54 & +0.69 & +0.93 \\
\hline 74.0 & 8.36 & 162.65 & 0.49 & 79.70 & 75 & 59.77 & 2.83 & +56.94 & +8.77 & +0.71 & +0.95 \\
\hline \multirow[t]{3}{*}{$\begin{array}{l}\text { Natural } \\
\text { particulates }\end{array}$} & 0.88 & 5.31 & 0.49 & 2.60 & 40 & 1.04 & 2.83 & -1.79 & -0.27 & -0.69 & -1.72 \\
\hline & 3.28 & 19.81 & 0.49 & 9.71 & 40 & 3.88 & 2.83 & +1.05 & +0.16 & +0.11 & +0.27 \\
\hline & 5.68 & 34.31 & 0.49 & 16.81 & 40 & 6.72 & 2.83 & $\begin{array}{r}+3.89 \\
\end{array}$ & +0.60 & +0.23 & +0.58 \\
\hline Kelp fragments & 3.00 & 29.1 & 0.49 & 14.26 & 40 & 5.70 & 2.83 & +2.87 & +0.44 & +0.20 & +0.50 \\
\hline
\end{tabular}


Table 8. Pyura stolonifera. Energy balance in a Natal population. Combination of data from present study on ingestion rate and loss of energy by respiration with that of Berry (1982) on population biomass and production. Energy content of suspended matter in Natal waters $\left(60.0 \mathrm{~J} \mathrm{l}^{-1}\right)$ adapted from Berry and Schleyer (1983)

\begin{tabular}{|c|c|c|c|c|c|c|c|c|}
\hline $\begin{array}{l}\text { Sampling } \\
\text { interval } \\
\text { (d) } \\
\text { and season }\end{array}$ & $\begin{array}{c}\text { Mean } \\
\text { flesh weight } \\
\text { indiv } \\
\text { (g) }\end{array}$ & $\begin{array}{l}\text { Mean } \\
\text { population } \\
\text { density } \\
\left(\mathrm{m}^{-2}\right)\end{array}$ & $\begin{array}{c}\text { Total } \\
\text { production } \\
\text { (tunic }+ \text { flesh) } \\
\left(\mathrm{kJ} \mathrm{m}^{-2}\right)\end{array}$ & $\begin{array}{c}\text { Mean } \\
\mathrm{Fr} \\
\left(1 \mathrm{~m}^{-2} \mathrm{~h}^{-1}\right)\end{array}$ & $\begin{array}{c}\text { Total } \\
\text { energy } \\
\text { ingested } \\
\left(\mathrm{kJ} \mathrm{m}^{-2}\right)\end{array}$ & $\begin{array}{c}\text { Mean } \\
\mathrm{R} \\
\left(\mathrm{ml} \mathrm{O}_{2} \mathrm{~m}^{2} \mathrm{~h}^{-1}\right)\end{array}$ & $\begin{array}{c}\text { Total } \\
\text { energy } \\
\text { respired } \\
\left(\mathrm{k} \mathrm{Jm}^{-2}\right)\end{array}$ & $\begin{array}{c}P+R \\
\left(\mathrm{k} \mathrm{Jm}^{-2}\right)\end{array}$ \\
\hline 66 Summer & 0.09 & 226.5 & 1471 & 20.4 & 1938 & 3.2 & 101 & 1572 \\
\hline 61 & 0.20 & 333.0 & 2449 & 52.6 & 4622 & 10.1 & 294 & 2744 \\
\hline 36 Autumn & 0.39 & 306.5 & 4500 & 77.5 & 4017 & 17.5 & 301 & 4801 \\
\hline 16 & 0.56 & 283.5 & 1746 & 97.6 & 2248 & 22.9 & 174 & 1920 \\
\hline 48 & 0.63 & 280.5 & 2244 & 99.3 & 6863 & 25.3 & 579 & 2823 \\
\hline 26 Winter & 0.70 & 271.5 & 1107 & 103.5 & 3875 & 27.1 & 336 & 1443 \\
\hline 29 & 0.79 & 250.5 & 781 & 104.0 & 4343 & 28.0 & 387 & 1168 \\
\hline 26 & 0.86 & 219.5 & 3003 & 96.7 & 3620 & 26.6 & 330 & 3333 \\
\hline 28 Spring & 1.05 & 191.5 & 3024 & 97.1 & 3915 & 28.1 & 374 & 3398 \\
\hline Totals & & & 20325 & & 35441 & & 2876 & 23201 \\
\hline
\end{tabular}

therefore appear to show no evidence of limiting their energy uptake under natural conditions and are adapted to utilize fully fluctuations in energy available in the particulate matter suspended in the water column. In fact, such fluctuations are characteristic of the kelp bed system as a result of the dynamic states accompanying upwelling and downwelling (Wulff and Field, 1983).

In a study of a surf-zone reef on the Natal Coast, Berry (1982) found that the mussel Perna perna was usually the dominant inhabitant, but on 2 occasions there were settlements of Pyura stolonifera. In both cases the ascidian suffered mass mortality as a result of competition with the mussel. Berry's data on the biomass and production of the second cohort have been compared with components of energy utilization as calculated in the present study (Table 8). The Natal waters contain on average $3.16 \mathrm{mg} \mathrm{l}^{-1}$ particulate organic matter (2 to $100 \mu \mathrm{m}$ ) equivalent to $60 \mathrm{~J}^{-1}$ (Berry and Schleyer, 1983). This energy content is 3 times that of SW Cape waters (Griffiths 1980b; Stuart, 1982). From information on the relation between filtration and respiration rates and size in $P$. stolonifera it was calculated that the population on the Natal reef ingested a total of $35,441 \mathrm{~kJ} \mathrm{~m}^{-2} \mathrm{yr}^{-1}$, i.e. 1.5 times the energy invested in growth and maintenance. Since only $42 \%$ of ingested ration is assimilated in nature, the useful energy accounts for only $64 \%$ of requirements. However, if the full size range of average particulate organic matter on the Natal reef (5.873 $\mathrm{mg} \mathrm{1}^{-1}$ ) were available to the ascidian, this would satisfy $119 \%$ of its estimated energy needs.

Absolute rates of filtration in Pyura stolonifera are within the range reported for other large advanced ascidians, but weight specific rates in $P$. stolonifera are much lower than in all other species studied (Table 1). Nevertheless - given the quantity and energy content of suspended particulate matter in the waters where $P$. stolonifera occurs - it is apparent that the estimated filtration rate provides for a high ingestion rate and a positive energy balance in nature.

Acknowledgements. I am grateful to Professor J. G. Field, Dr. C. Griffiths and other members of staff of the Zoology Department at U.C.T. for generous assistance, hospitality and discussion throughout this study. I also thank Mr. H. Hennig of CSIR for providing some equipment and the algal cultures; Dr. B. L. Bayne, Professor J. G. Field and several reviewers for helpful criticism of the manuscript; and Mrs. C. Schuster for typing. The award of a University of Cape Town Research Fellowship and the additional funding through the Benguela Ecology Programme of SANCOR is gratefully acknowledged.

\section{LITERATURE CITED}

Bayne, B. L., Newell, R. C. (1983). Physiological energetics of marine molluscs. In: Wilbur, K. M. (ed.) The mollusca, Vol. 4. Academic Press, New York, p. 407-514

Bayne, B. L., Thompson, R. J., Widdows, J. (1976). Physiology 1. In: Bayne, B. L. (ed.) Marine mussels, their ecology and physiology. Cambridge University Press, Cambridge, p. $121-206$

Berry, P. F. (1982). Biomass and density of detritivores on a littoral rocky reef on the Natal Coast, with an estimate of population production for the ascidian Pyura stolonifera. Investl Rep. oceanogr. Res. Inst. S. Afr. Ass. mar. Biol. Res. 53: $1-15$

Berry, P. F., Schleyer, M. H. (1983). The brown mussel Perna perna on the Natal coast South Africa: utilization of available food and energy budget. Mar. Ecol. Prog. Ser. 13: 201-210 
Burky, A. J., Farmanfarmaian, A. (1965). Effect of cold temperature acclimation and size on the respiration of ascidians. Biol. Bull. mar biol. Lab., Woods Hole 129: 401

Carlisle, D. B. (1966). The ciliarly current of Phallusia (Ascidiacea) and the squirting of sea squirts. J. mar. biol. Ass. U. K. 46: 125-127

Christie, N. D., Moldan, A. (1977). Distribution of benthic macrofauna in Langebaan Lagoon. Trans. R. Soc. S. Afr. 42: $273-283$

Cliff, G. (1982a), Seasonal variation in the contribution of phytoplankton, bacteria, detritus and inorganic nutrients to a rocky shore ecosystem. Trans. R. Soc. S. Afr. 44 $523-538$

Cliff, G. (1982b). Dissolved and particulate matter in the surface waters of False Bay and its influence on the rocky shore ecosystem. Trans. R. Soc. S. Afr. 44: 539-549

Conover, R. J. (1966). Assimilation of organic matter by zooplankton. Limnol. Oceanogr. 11: 338-354

Dakin, W. J., Bennett, I., Pope, E. (1948). A study of certain aspects of the ecology of the intertidal zone of the New South Wales coast. Aust. J. scient. Res. Ser. B 2: 173-230

Day, J. H. (1969). A guide to the marine life of South African shores. Balkema, Cape Town

Day, R. W. (1974). An investigation of Pyura stolonifera (tunicata) from the Cape Peninsula. Zool. Afr. 9: 35-58

Du Plessis, A. J. (1977). Larval development, settlement and growth of the black mussel Choromytilus meridionalis in the Saldanha Bay region. Trans. R. Soc. S. Afr. 42: 303-315

Fiala-Medioni, A. (1973). Filter-feeding ethology of benthic invertebrates (Ascidians). I. Experimental apparatus. Rates of filtration and digestion of Phallusia mammillata Mar. Biol. 23: 137-145

Fiala-Medioni, A. (1974). Filter-feeding ethology of benthic invertebrates (Ascidians). II. Variations in filtration and digestion rates as a function of species. Mar. Biol. 28: 199-206

Fiala-Medioni, A. (1978a). Filter-feeding ethology of benthic invertebrates (Ascidians). III. Recording of water current in situ-rate and rhythm of pumping. Mar. Biol. 45: 185-190

Fiala-Medioni, A. (1978b). Filter-feeding ethology of benthic invertebrates (Ascidians). IV, Pumping rate, filtration rate, filtration efficiency. Mar. Biol. 48: 243-249

Fiala-Medioni, A. (1978c). Filter-feeding ethology of benthic invertebrates (Ascidians). V Influence of temperature on pumping, filtration and digestion rates and rhythms in Phallusia mammillata. Mar. Biol. 48: 251-259

Fiala-Medioni, A. (1979a). Influence of algal concentration on pumping, filtration and absorption rates of Phallusia mammillata (Cuvier, 1915) (Ascidian). Annls Inst. océanogr., Monaco 55: 155-162

Fiala-Medioni, A. (1979b). Effects of oxygen tension on pumping, filtration and oxygen uptake in the ascidian Phallusia mammillata. Mar. Ecol. Prog. Ser. 1: 49-53

Field, J. G., Griffiths, C. L., Griffiths, R. J., Jarman, N., Zoutendyk, P., Velimirov, B., Bowes, A. (1980a). Variation in structure and biomass of kelp communities along the south west Cape coast. Trans. R. Soc. S. Afr. 44: 145-203

Field, J. G., Griffiths, C. L., Linley, E. A., Carter, R. A., Zoutendyk, P. (1980b). Upwelling in a nearshore marine ecosystem and its biological implications. Estuar. coast. mar. Sci. 11: 133-150

Fisher, T. R. (1976). Oxygen uptake of the solitary ascidian Styela plicata. Biol. Bull. mar. biol. Lab., Woods Hole 151: 297-305

Griffiths, C. L., King, J. A. (1979). Some relationships between size, food availability and energy balance in the ribbed mussel Aulacomya ater. Mar. Biol. 51: 141-149
Griffiths, R. J. (1975). The larval development of Pyura stolonifera (Tunicata). Trans. R. Soc. S. Afr. 42: 1-9

Griffiths, R. J. (1980a). Filtration, respiration and assimilation in the black mussel Choromytilus meridionalis. Mar. Ecol. Prog. Ser. 2: 63-70

Griffiths, R. J. (1980b). Natural food availability and assimilation in the bivalve Choromytilus meridionalis. Mar Ecol. Prog. Ser. 3: 151-156

Harbison, G. R., McAlister, V. L. (1979). The filter-feeding rates and particle retention efficiency of three species of Cyclosalpa (Tunicata, Thaliacea). Limnol. Oceanogr. 24: 875-892

Hecht, S. (1916). The water current produced by Ascidia atra Lesueur. J. exp. Zool. 20; 429-434

Henry, J. L., Mostert, S. A., Christie, N. D. (1977). Phytoplankton production in Langebaan Lagoon and Saldanha Bay. Trans. R. Soc. S. Afr. 42: 383-398

Hildreth, D. I., Crisp, D. J. (1976). A corrected formula for calculation of filtration rate of bivalve molluscs in an experimental flowing system. J. mar. biol. Ass. U. K. 56: $111-120$

Holmes, N. (1973). Water transport in the ascidians Styela clava Herdman and Ascidiella aspersa (Müller). J. exp. mar. Biol. Ecol. 11: 1-13

Hoyle, G. (1953). Spontaneous squirting of an ascidian, Phallusia mammillata Cuvier. J. mar. biol. Ass. U. K. 31: $541-562$

Jørgensen, C. B. (1949). Feeding rates of sponges, lamellibranchs and ascidians. Nature, Lond. 163: 912

Jergensen, C. B. (1952). On the relation between water transport and food requirements in some marine filter feeding invertebrates. Biol. Bull. mar. biol. Lab., Woods Hole 103: 356-363

Jergensen, C. B., Goldberg, E. D. (1953). Particle filtration in some ascidians and lamellibranchs. Biol. Bull. mar. biol. Lab., Woods Hole 105: 477-489

Mazure, H. G. F., Branch, G. M. (1979). A preliminary analysis of bacterial numbers and biomass in Langebaan Lagoon. Trans. R. Soc. S. Afr. 44: 43-54

McGinitie, G. E. (1939). The method of feeding of tunicates. Biol. Bull. mar. biol. Lab., Woods Hole 77: 443-447

McQuaid, C. D. (1980). Spatial and temporal variations in rocky intertidal communities. Ph. D. thesis, University of Cape Town

Millar, R. H. (1960). Ascidiacea. 'Discovery' Rep. 30: 1-160

Millar, R. H. (1971). The biology of ascidians. Adv. mar. Biol 9: $1-100$

Møhlenberg, F., Riisgård, H. U. (1978). Efficiency of particle retension in thirteen species of suspension feeding bivalves. Ophelia 17: 239-246

Morgans, J. F. (1959). The benthic ecology of Table Bay. Trans. R. Soc. S. Afr, 35: 387-442

Newell, R. C., Field, J. G., Griffiths, C. L. (1982). Energy balance and significance of microorganisms in a kelp bed community. Mar. Ecol. Prog. Ser. 8: 103-113

Randløv, A., Riisgård, H. U, (1979). Efficiency of particle retension and filtration rate in four species of ascidians. Mar. Ecol. Prog. Ser. 1: 55-59

Robbins, I. J. (1983). The effects of body size, temperature and suspension density on the filtration and ingestion of inorganic particulate suspensions by ascidians. J. exp. mar. Biol. Ecol. 70: 65-78

Strickland, J. D. H., Parsons, T. R. (1968). A practical handbook of seawater analysis. Bull. Fish. Res. Bd Can. 167: $1-311$

Stuart, V. (1982). Absorbed ration, respiratory costs and resultant scope for growth in the mussel Aulacomya ater 
(Molina) fed on a diet of kelp detritus of different ages. Mar. Biol. Lett. 3: 289-306

Stuart, V., Field, J. G., Newell, R. C. (1982). Evidence for the absorption of kelp detritus by the ribbed mussel Aulacomya ater (Molina) using a new ${ }^{51} \mathrm{Cr}$-labelled microsphere technique. Mar. Ecol. Prog. Ser. 9: 263-271

Stuart, V., Klumpp, D. W. (1984). Evidence for food resource partitioning by kelp-bed filter-feeders. Mar. Ecol. Prog. Ser. 16: 27-37

Van Driel, C. D. (1978). Aspekte van die biologie van Pyura stolonifera (Tunicata: Ascidiacea) in Algoabaai met spesiale verwysing na die energiemetabolisme. Ph. D. thesis, University of Port Elizabeth

Velimirov, B., Field, J. G., Griffiths, C. L., Zoutendyk, P. (1977). The ecology of kelp-bed communities in the Ben- guela upwelling system. Helgoländer wiss. Meeresunters. 30: 495-518

Werner, E., Werner, B. (1954). Uber den Mechanismus des Nahrungserwerbs der Tunicaten, speciell der Ascidien. Helgoländer wiss. Meeresunters. 5: 57-92

Winberg, G. G. (1956). Rate of metabolism and food requirements of fishes. Fish. Res. Bd Can. (Transl. Ser.) 194

Winter, J. E. (1969). Über den Einfluß der Nahrungskonzentration und anderer Faktoren auf Filtrierleistung und Nahrungsausnutzung der Muscheln Arctica islandica und Modiolus modiolus. Mar. Biol, 4: 87-135

Wulff, F. V., Field, J. G. (1983). Importance of different trophic pathways in a nearshore benthic community under upwelling and downwelling conditions. Mar. Ecol. Prog. Ser. 12: $217-228$

This paper was submitted to the editor; it was accepted for printing on June 23, 1984 